\title{
Evaluation of Factors Influencing on Development of Export in SMEs
}

\author{
Mansoureh Aligholi \\ Department of Business Management, Faculty of Management, Central Tehran Branch, Islamic Azad University, Tehran, Iran. \\ Assistant Professor, Department of Business Management, Faculty of Management, \\ Central Tehran Branch, Islamic Azad University, Tehran, Iran. \\ Email: man.aligholi@iauctb.ac.ir
}

\section{Doi:10.5901/mjss.2014.v5n20p3010}

\section{Abstract}

The present research tries to evaluate the influence of factors that are effective in development of export in SMEs in Ardebil province in Iran. It aims to investigate the influence of each of the components competition in internal market, company size, goods packaging, manager's skill in destination country language and elimination of procedural obstacles on export development. Questionnaire was used to gather data. Questionnaires were distributed in active SMEs in 2 industrial estates in Ardebil city and finally, 157 questionnaires were collected. Lisrel software and structural equations modeling were used to analyze data. All hypotheses were verified at the end of the research.

Keywords: SMEs, Export, Import

\section{Introduction}

Today, in most countries SMEs play role in different social, industrial and service aspects. In many of these countries, SMEs are providers of new jobs, innovation and new technologies. In developing and developed countries, there has been proved a close relationship between SMEs and socio-economic advancements.

Although theories related to SMEs are traced back to one century before and classic theorists have proposed it, the mentioned theory has received a lot of attention within the framework of entrepreneurship. In general, it can be said that development of SMEs cause change in four dimensions:

Social dimensions: it means development of firms cause increase in occupation. Such firms are interested in workrelated techniques than capital-related techniques.

Economic dimensions: it means distribution of income becomes more homogeneous and many social tensions are prevented.

Political dimensions: opportunities are distributed among people and monopoly is prevented, some people also consider it as a step towards development of democracy and civil society.

Personal dimensions: this dimension means that a more appropriate space will be provided for expression of economic humans creativities.

Changes in these four dimensions are accompanied by a type of increase in dynamism and flexibility against global changes. In advanced countries, SMEs have special importance in economic equilibrium. Growth in such firms is not dependent on capital and initiative, seizure of opportunities and application of suitable marketing methods are important. SMEs have decisive roles in creating occupation and boom in economic conditions from international institutes like global bank and International Money Fund; some developing and developed countries especially in eastern and south-eastern Asia have been able to take important steps in reducing economic and social crises like unemployment. Therefore, it seems necessary to conduct studies in the field of SMEs.

\section{Theoretical Literature}

\subsection{SMES}

Within the past few years, many plans have been implemented to contribute to the growth and development of SMEs in national and international levels. However, the result of these actions will not be measurable until these firms are defined well. Definitions presented for SMEs are similar in different countries, but there is no single definition (Edraki, 2008). Most 
of these definitions have been proposed based on quantitative criteria like number of employees and annual financial circulation. For example, firms which have employees below 500 people are called small companies in USA, while in Germany, companies with fewer than 10 employees are called small companies and medium companies are those which have employees between 10 and 499 (Salavati, Maddah and Yazdani, 2008).

Table 1. Classification of companies based on SMEs definition provided by European Commision

\begin{tabular}{|c|c|c|}
\hline \multirow{2}{*}{ Company type } & \multirow{2}{*}{ Number of employees } & Financial condition of companies (million euro) \\
\cline { 3 - 3 } & 1 to9 & Financial circulation \\
\hline )Micro( & 10 to 49 & $\leq 2$ \\
\hline Small( & 50 to249 & $\leq 10$ \\
\hline Medium( & & $\leq 50$ \\
\hline
\end{tabular}

SMEs are commercial-production firms that are lower than large companies in terms of size. Classification of these firms is usually based on the following four indices:

1. number of employees, 2. Sum of net assets, 3. Sales amount of firms, 4. Firm investment amount

Number of employees is the commonest index for definition of SMEs size. Although this index is different all over the world, but many countries define SMEs in terms of number of employees in a spectrum from 1 to 250 employees (Zadeh Vakili, 2006).

It seems that the size of firms and their ability in bearing different economic conditions are important in classification of industries into small, medium and large based on the number of employees and investment volume or whatever. There is no doubt that large industries and especially public industries have more power in confrontation with problems due to access to wider financial resources and their conservation is rarely threatened. But small and private sector companies are faced with more problems and must be supported because they play important role in economy.

\subsection{Competition in internal market and export}

Salivan and Bourch Mit (1988) stated that internal market conditions can direct companies towards external markets. Variations in demand sever competition in internal market, low annual growth rate and small market size can lead companies towards export markets for conservation (Tuget-nguyen, 2000). According to international Buckley theory (1990), companies develop in internal market when the costs of development in internal market are lower than the costs of development in international markets (Buckley, 1990). Kavousgil (1982) stated that great experience in internal market is like an additional advantage which facilitates export. Companies may develop internal markets before starting to export and in internal market; they gather experience for exporting strategies (Tuget nguyen, 2000).

\subsection{Company size and export}

Many studies have shown that companies' size is an important factor in their tendency to export their products (Burton and Schlegelmilch, 1987. Hirsch. and Adar, 1974. Reid, 1984). The greater is the size of a company, the more is its interest and power to export its products. This matches the fact that large companies have more managerial and financial resources and therefore greater tendency to export (Cavusgil, S.T. and Naor, 1987. Reid,1984). Although many studies verified this result, Aaby and Slater faced a kind of contradiction and concluded that large size of companies does not necessarily result in export increase. Their research (1989) showed that there is no significant relationship between company size and export increase. In spite of this, it is unanimously accepted that large companies have many resources, benefit from economy of scale and do not think about export risk as much as small companies (Bonaccorsi, 1992). According to what was said up to now, it is assumed that managerial perceptions of export difficulties are different in SMEs and large companies; so that in large companies, export difficulties are considered less in comparison with SMEs and large companies do not regard this factor as a preventing factor.

\subsection{Packaging and export}

Packaging is one of the dimensions of product quality. Packaging is very important in competitive markets and has received a lot of attention because it is an important tool in marketing communication and therefore it is important for establishment of relationship and product branding (Silayoi \& Speece, 2005). Today, businesses move towards 
globalization and they pay attention to competitive advantages in order to stay in global markets. in the process of creating competitive advantage, a company needs to identify success key factors and also have necessary capacity for this. Products packaging is one of these key factors. Many studies emphasize on symbolic and information and convenience role of packaging (Prendergest \& Pitt, 1996), but Rand (2005) believes that packaging can bring competitive advantage.

\subsection{Destination country language}

In 1991, herbig and carmer stated that the world is becoming smaller and smaller in terms of business pressure. If you don't try to sell your products abroad, you will have to compete against external products. Growth of international commerce, growth of dependence of macro-economies on each other, transfer of technology from one country to another country and international transactions make you become familiar with other countries culture and language. One of the main ways of establishment of relationship with SMEs in other countries is language. This can be an important problem in establishment of relationship (Crick, 1999). Swift (1991) defined language as speech, individuals' language and the words individuals use and the way of making speech. Some researchers widened this definition and stated that language is only one communication mechanism among other mechanisms like image, audio, sense of smell and touch (Steiner, 1977).

eckart and peel (1997) conducted a research and showed that SMEs consider language as an important factor in companies export. In 1992, a researcher concluded that many companies do large investments in teaching in order to increase their export (Hagen, 1992). Furthermore, this researcher conducted another research in 1998 and concluded that SMEs lose many opportunities because of lack of abilities in foreign languages. The following studies also refer to language as an important factor in export (Shane,1988; Ferney, 1989; Holden, 1989; Edwards, 1990; Rushby, 1990; Swift, 1990;Metcalf, 1991; Schloss, 1991; Swift and Swift, 1992; Evening Standard, 1993; Miles, 1993; Linguatel, 1995a; 1995b; Marschan et al., 1997).

Therefore, this paper tries to investigate foreign languages as an important factor in export operation of SMEs.

\subsection{Procedural barriers}

Export needs knowledge on export procedures. One important factor is related to the time and bureaucracy of completion of internal and external market regulations. These regulations are not imposed by governments only but independent organizations like banks, insurance companies and transportation organizations and ... have their own regulations. Therefore, lack of information on export procedures is an export barrier (haidari, 1999, 23). A company which is trying to enter export markets or increase its export activity has to acquire necessary information on executive procedures. In fact, it is difficult for mangers with low experience to deal with external documents and bureaucracy. Brook and Francis (1991) stated that when the government becomes large in a country and supervises on everything, formal procedures lead to bureaucracy and this makes it difficult for managers to enter export market (Brooks and Francis, 1991, 80). If managers face complexity in dealing with documents, this has negative influence on companies export sales and if complexity of documents is low, companies performance will improve.

\section{Research Conceptual Framework}

The framework presented in figure 1 is the conceptual model of this research. This model shows causal relationships between five variables (competition in internal market, company size, products packaging, manager's skill in destination country language and development of export). 
Figure 1: research conceptual model

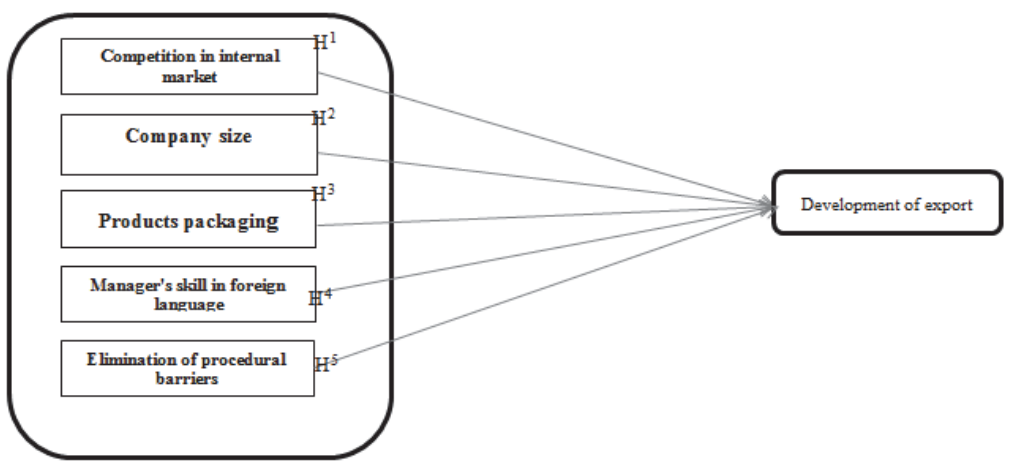

Research hypotheses are formulated based on the conceptual model as follows:

\section{Research Hypotheses}

$\mathrm{H}_{1}$ : competition in internal market influences directly on export development.

$\mathrm{H}_{2}$ : company size influences directly on export development.

$\mathrm{H}_{3}$ : products packaging influences directly on export development.

$\mathrm{H}_{4}$ : managers' skill in foreign languages influences directly on export development.

$\mathrm{H}_{5}$ : elimination of procedural barriers influences directly on export development.

\section{Materials and Methods}

\subsection{Questionnaire}

In the present research, questionnaire was used to gather data. \%-point Likert scale was used to measure variables. In order to measure latent variables, 4 questions were considered for competitive condition, 4 questions were considered for company size, 4 questions were considered for packaging, 3 questions were considered for skill in foreign language, 4 questions were considered for procedural barriers and 4 questions were considered for export development. 20 questionnaires were distributed for pretest and in order to check reliability and Cronbach's alpha was greater for all variables and therefore, the questionnaire had necessary reliability. Validity of the questionnaire was also verified by experts. 264 SMEs which were active in Ardebil Province industrial estates were identified. Sample size was calculated to be 157 people by means of Morgan table.

\subsection{Data analysis}

Structural equations modeling were used to analyze data. this model contains other techniques like multi-variate regression, factor analysis and path analysis and its main emphasis is on latent variables which are defined by measurable indices and tacit variables. In structural equations modeling we try to find whether the relationships between latent characteristics are verified or not? Lisrel software was used to handle calculations.

Research model must be appropriate for investigation of relationships among variables and this can be checked by means of goodness of fit indices in the output of Lisrel. Table 1 shows fit indices for the present research model. 
Table 2. Model fitness indices

\begin{tabular}{|l|c|c|}
\hline Indices & Allowable value & Calculated numbers \\
\hline Ratio of $X$-squared on degree of freedom & $/ \mathrm{df}<3 \chi^{2}$ & 1.97 \\
\hline P value & $<0.05 \mathrm{p}$ value & 0.0000 \\
\hline RMSEA & RMSEA $<0.08$ & 0.060 \\
\hline Fitting index & greater than 0.9 & 0.91 \\
\hline Comparative fitting index & greater than 0.9 & 0.94 \\
\hline Normalized fitting index)NFI( & greater than 0.9 & 0.93 \\
\hline
\end{tabular}

As it can be seen on table 4, all fit indices were at satisfactory level and this shows that the model of research is good for investigation (X-squared to DF is 1.97, $\mathrm{p}$ value is equal to 0.00 , RMSEA is equal to 0.06 , goodness of fit index is equal to 0.91, comparative fit index is equal to 0.94 and normalized fit index is equal to 0.93 . in order to investigate the hypotheses, results of Lisrel software calculations were used in 2 cases of standard case (figure 2) and research model in significance state (figure 3).

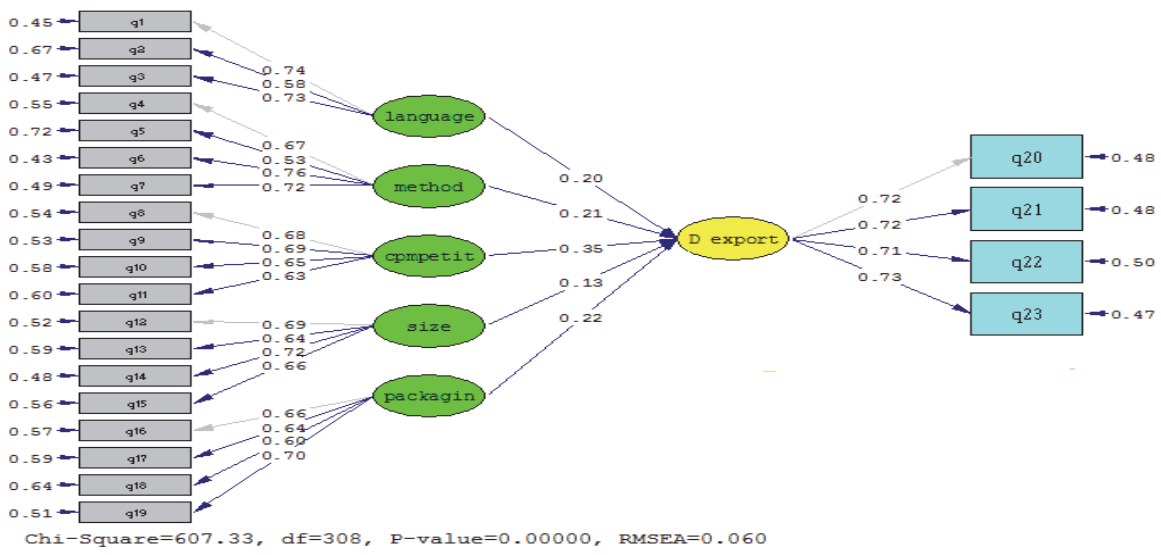

Figure 2. Research model in standard case

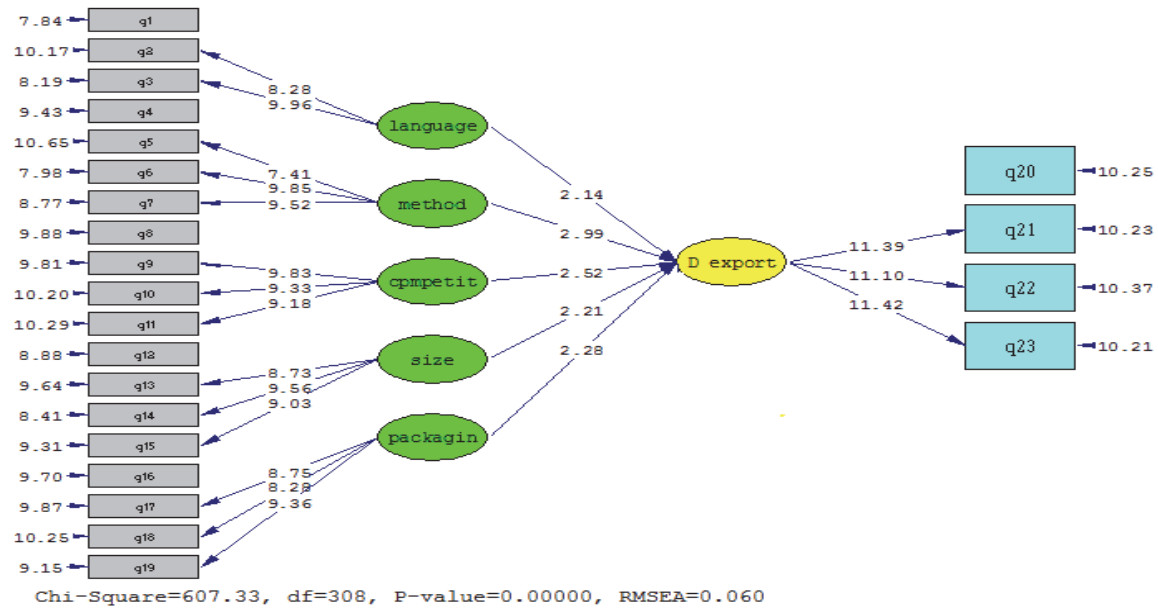

Figure 3. Research model in significance case 
Considering the fact that significance level is $0.95 \%$ for tests, therefore all hypotheses whose significance number is outside the range of +1.96 and -1.96 are accepted. In the next sentences, research hypotheses are investigated by means of research model in significance and standard cases.

H1: competition in internal market has direct influence on export development. Results of investigations showed that presence of internal competition with standard factor loading equal to 0.35 and $t=2.52$ influences on export development and this shows that the first hypothesis is verified. In other words, as competition in internal market increases, it can have positive and direct influence on SMEs export.

$\mathrm{H} 2$ : company size has direct influence on export development. Results of investigations showed that company size with standard factor loading equal to 0.13 and $t=2.21$ influences on export development and this shows that the second hypothesis is verified. In other words, as company size increases, it can have positive and direct influence on SMEs export.

H3: packaging has direct influence on export development. Results of investigations showed that packaging with standard factor loading equal to 0.22 and $t=2.28$ influences on export development and this shows that the third hypothesis is verified. In other words, as packaging improves, it can have positive and direct influence on SMEs export.

H4: manager's skill in foreign language has direct influence on export development. Results of investigations showed that manager's skill in foreign language with standard factor loading equal to 0.20 and $t=2.14$ influences on export development and this shows that the 4th hypothesis is verified. In other words, as manager's skill in foreign languages increases, it can have positive and direct influence on SMEs export.

H5: elimination of procedural barriers has direct influence on export development. Results of investigations showed that elimination of procedural barriers with standard factor loading equal to 0.21 and $t=2.99$ influences on export development and this shows that the fifth hypothesis is verified. In other words, as procedural barriers are eliminated, it can have positive and direct influence on SMEs export.

Summary of the results of investigation of research hypotheses has been provided in table 2 .

Table 3: results of research hypotheses tests

\begin{tabular}{lccc}
\hline Hypotheses & Significance number (T) & Path analysis (standard) & result \\
\hline Competition in internal market----- development of export & 2.52 & 0.35 & verified \\
Company size----- development of export & 2.21 & 0.13 & verified \\
packaging----- development of export & 2.28 & 0.22 & verified \\
Manager's skill in destination country language------ & 2.14 & 0.20 & verified \\
development of export & 2.99 & 0.21 & verified \\
Elimination of procedural barriers------ development of export & &
\end{tabular}

\section{Conclusion and Discussion}

Today, in most countries SMEs play important roles in social and economic aspects. In many of these countries, SMEs are suppliers of new jobs, technologies and innovation. These firms play role in economic development of the countries with considerable amount of export. This is why SMEs have received a lot of attention in the recent years. Identification of factors affecting globalization of SMEs is therefore important. The present study aimed to answer "what are the factors influencing on export development in SMEs?". Research results showed that all factors competition in internal market, company size, products packaging, language and elimination of procedural barriers influence on development of export in SMEs. The government can provide necessary trainings, support materially and spiritually, strengthen export supporting centers and direct them towards international institutes and therefore take important steps in globalization facilitation. Procedural barriers, bureaucracy and problems ahead of export must be eliminated in order to facilitate export. Export can also be increased in SMEs if managers learn foreign languages and make their employees learn foreign languages. Competition conditions can also be improved by preventing from subsidy improper distribution among inefficient companies and therefore export can be facilitated for SMEs.

\section{References}

Aaby, N.E. and Slater, S.F., "Managerial Influences on Export Performance: A Review of the Empirical Literature 1978-88", International Marketing Review, Vol. 6 No. 4, 1989, pp. 53-68.

Bonaccorsi, A., "On the Relationship between Firm Size and Export Intensity", Journal of International Business Studies, Vol. 23 No. 4 , 1992, pp. 605-35. 
Buckley, P. (1990), "Problems and development in the core theory of international business", Journal of International Business Studies, Fourth Quarter, pp. 567-664.

Burton, F.N. and Schlegelmilch, B., "Profile Analysis of Non-exporters versus Exporters Grouped by Export Involvement", Management International Review, Vol. 27 No. 1, 1987, pp. 38-49.

Brooks, M.R. and Frances, A. (1991), "Barriers to exporting: an exploratory study of Latin American companies", in Seringhouse, F.H.R. and Rosson, P. (Eds), Export Development and Promotion: The Role of Public Organisations, Kluwer Academic Publishers,Boston, MA.

Cavusgil, S.T. and Naor, J., "Firm and Management Characteristics as Discriminators of Export-marketing Activity", Journal of Business Research, Vol. 15 No. 3, 1987, pp. 221-35.

Crick, D. and Chaudry, S. (1997), "Small business' motives for exporting: the effect of internationalization", Journal of Marketing Practice: Applied Marketing Science, Vol. 3No. 3, pp. 156-70.

Crick Dave. (1999), "An investigation into SMEs' use of languages in their export operations", International Journal of Entrepreneurial Behavior \& Research, Vol. 5 No. 1, 1999, pp. 19-31

Edwards, G. (1990), "It's OK, they all speak English", International Business Communication, Vol. 2 No. 2, pp. 8-12.

Edraki, Mohammad Reza (2008), " the bank of development of SMEs in Iran", specialized quarterly of parks and incubators, number 12.

Evening Standard (1993), "Breaking all language barriers", 22 November.

Ferney, D. (1989), "Language skills: is reactive training enough?", Journal of European Industrial Training, Vol. 14 No. 9, pp. 27-30.

Hagen, S. (1988), Languages in Business: An Analysis of Current Needs, Newcastle Polytechnic, Newcastle.

Hagen, S. (1992), "Language policy and strategy issues in the New Europe", Language Learning Journal, Vol. 5, pp. 31-4.

Haidari, I. (1999), "Leather and leather goods in Pakistan", Economic Review, Vol. 30, pp. 3.

Herbig, P.A. and Kramer, H.E. (1991), "Cross-cultural negotiations: success through understanding", Management Decision, Vol. 29 No. 8, pp. 19-31.

Hirsch, S. and Adar, Z., "Firm Size and Export Performance", World Development, Vol. 2 No. 7, 1974, pp. 41-6.

Holden, N.J. (1989), "Towards a functional typology of languages in international business", Language Problems and Language Planning, Vol. 13 No. 1.

Linguatel (1995a), Survey of Language Capabilities of Exporters in Mainland Europe.

Linguatel (1995b), A Survey into the Ability of Major UK Exporters to Handle Foreign Language Enquiries.

Marschan, R., Welch, D. and Welch, L. (1997), "Language: the forgotten factor in multinational

Management", European Management Journal, Vol. 15 No. 5, pp. 591-8.

Metcalf, H. (1991), Foreign Language Needs of Business, Institute of Manpower Studies Report No. 215.

Miles, L. (1993), "An Englishman abroad", Marketing Business, March, pp. 30-4.

Nasrin doost, Tayyebeh (2008), " situation of SMEs in Iran and some countries", mines and industries affaires office, Tehran.

pak,j.m.(1991). "The export behavior of firms: a study of determinants and decision making in small-and-medium-sized manufacturing firms", PH.D Dissertation, university of Alabama.

Peel, M.J. and Eckart, H. (1997), "Export and language barriers in the Welsh SME sector", Small Business and Enterprise Development, Vol. 4, pp. 31-42.

Prendergast, G. and Pitt, L. (1996), "Packaging, marketing logistics and the environment: are there trade-offs?", International Journal of Physical Distribution \& Logistics Management,Vol. 26 No. 6, pp. 60-72.

Reid, S., "Information Acquisition and Export Entry Decisions in Small Firms", Journal of Business Research, Vol. 12, 1984, pp. $141-57$.

Rushby, N. (1990), "Beyond the language lab", Personnel Management, February, p. 71.

Schloss, S. (1991), "From lay-bys to languages", Industrial Society Magazine, June, pp. 16-17.

Salavati Sarcheshmeh, Bahram. Maddah, Masoumeh. Yazdani Rad, Ehsan (2008), " framework of policy-making and planning for supporting the creation and development of SMEs", specialized quarterly of parks and incubators, number 12.

Shane, S. (1988), "Language and marketing in Japan", International Journal of Advertising, Vol. 7, pp. 155-61.

Steiner, G. (1977), After Babel: Aspects of Language and Translation, Oxford University Press, Oxford.

Subrahmanya, M.H. Bala,(2007)," Development strategies for Indian SMEs: promoting linkages with global transnational corporations ", Management Research News Vol. 30 No. 10, 2007pp. 762-774.

Swift, J.S. (1990), "Marketing competence and language skills: UK firms in the Spanish market", International Business Communication, Vol. 2 No. 2, pp. 22-6.

Swift, J.S. (1991), "Foreign language ability and international marketing", European Journal of Marketing, Vol. 25 No. 12, pp. 36-49.

Swift J.S. and Swift, J.W. (1992), "Attitudes to language learning", Journal of European Industrial Training, Vol. 16 No. 7, pp. 7-15.

Zadeh Vakili, Kamran (2006), " SMEs", website of Organization commerce development 